\title{
Copyright exceptions and contract in the UK: the impact of recent amendments
}

Article

Accepted Version

Aronsson-Storrier, A. (2016) Copyright exceptions and contract in the UK: the impact of recent amendments. Queen Mary Journal of Intellectual Property, 6 (1). pp. 111-123. ISSN 20459815 doi: https://doi.org/10.4337/qmjip.2016.01.06 Available at https://centaur.reading.ac.uk/51585/

It is advisable to refer to the publisher's version if you intend to cite from the work. See Guidance on citing.

To link to this article DOI: http://dx.doi.org/10.4337/qmjip.2016.01.06

Publisher: Edward Elgar Publishing Ltd

All outputs in CentAUR are protected by Intellectual Property Rights law, including copyright law. Copyright and IPR is retained by the creators or other copyright holders. Terms and conditions for use of this material are defined in the End User Agreement.

\section{www.reading.ac.uk/centaur}

\section{CentAUR}

Central Archive at the University of Reading

Reading's research outputs online 


\section{Copyright exceptions and contract in the UK: the impact of recent amendments}

\section{Key words:}

COPYRIGHT EXCEPTIONS, CONTRACT, COPYRIGHT, COPYRIGHT DESIGNS AND PATENTS ACT

1988

\section{Abstract:}

In June and October 2014 a number of amendments to the Copyright, Designs and Patents Act 1988 came into effect, introducing new copyright exceptions and amending several existing exceptions. Whilst following recent judicial review the private copying exception has been quashed, many of the remaining new exceptions significantly alter the relationship between copyright exceptions and contract, making contractual terms unenforceable where those terms restrict users from taking advantage of an exception.

This paper explores the rationale for the UK amendments and considers whether the changes, as implemented, prevent rightsholders from contracting out of exceptions and whether they increase the clarity of the copyright system. 


\section{Copyright exceptions and contract in the UK: the impact of recent amendments}

\section{Introduction}

On 1 June and 1 October 2014 a number of amendments to the Copyright, Designs and Patents Act 1988 ('CDPA') came into effect, introducing new copyright exceptions and amending a number of existing exceptions. While most discussion of these amendments has focused on the merits and legality of introducing new categories of fair dealing copyright exceptions (including private copying and parody), many of the new exceptions significantly alter the relationship between copyright exceptions and contract within their sphere of application. For example, the new parody exception provides that 'to the extent that a term of a contract purports to prevent or restrict the doing of any act which, by virtue of this section, would not infringe copyright, that term is unenforceable'. ${ }^{1}$ While the decision to introduce a copyright exception permitting purchasers of content to make a copy for their own private use was subject to an application for judicial review and ultimately quashed, ${ }^{2}$ the remaining amendments to other new and amended provisions in the CDPA make contract terms which purport to restrict other exceptions unenforceable. This is notable

\footnotetext{
${ }^{1}$ CDPA 1988 s 30A(2) (as amended).

${ }^{2}$ See $R$ (on the application of BASCA \& Ors v Secretary of State for Business, Innovation and Skills [2015] EWHC 1723 (Admin) and $R$ (on the application of BASCA \& Ors v Secretary of State for Business, Innovation and Skills [2015] EWHC 2041 (Admin), discussed in section 2.2 below.
} 
because prior to the recent amendments it was generally considered possible to 'contract out' of most of the copyright exceptions in the $\operatorname{CDPA}^{3}$ (with the exception of certain specific exceptions relating to database and computer programs and the fair dealing for the purpose of reporting current events exception as relating to news reporting of visual images from broadcast or cable programmes). ${ }^{4}$ Some evidence collected prior to the amendments suggested that it was common business practice in many industries for copyright contracts to purport to restrict users' ability to make use of copyright exceptions. ${ }^{5}$

This paper introduces the law reform process that led to the amendments and identifies the rationale of the UK Government in altering the relationship between copyright and contract. It then explores areas where the remaining new amendments may not meet the Government's goal to prevent rightsholders from using contract to undermine the benefit of the exceptions. For example, some core public interest exceptions within the CDPA have been unamended and remain subject to contractual override. The Government's goal of increasing the clarity of permitted acts in the UK is also undermined by a lack of certainty as to the consequences of a provision being unenforceable rather than void.

\footnotetext{
${ }^{3}$ R Burrell and A Coleman, Copyright Exceptions: The Digital Impact (Cambridge University Press, Cambridge 2005) 69.

${ }^{4}$ As discussed below, exceptions relating to computer programs in section 50A of the CDPA 1988 have however long provided that contractual terms inconsistent with the exceptions are void. Similarly s 137 of the Broadcast Act 1996 makes contractual terms void where they seek to prohibit or restrict a fair dealing for the purpose of reporting current events in s 30(2) CDPA.

${ }^{5}$ See M Kretschmer and others, The relationship between copyright and contract law (Research commissioned by the Strategic Advisory Board for Intellectual Property Policy, 2010), <http://eprints.bournemouth.ac.uk/16091/1/_contractlaw-report.pdf > accessed 1 September 2015,141 - 142 and the studies referred to therein.
} 


\section{The UK amendments and the legislative amendments process}

\subsection{What are the amendments?}

The changes to the CDPA which came into effect on 1 June and 1 October 2014

included new and amended copyright exceptions. The new exceptions permit users to engage in fair dealing with a copyright protected work to engage in quotation, parody, text and data mining. ${ }^{6}$ The changes also included amendments to existing exceptions, including those relating to research and private study, disability, public administration, and educational establishments and libraries. These changes were made by the passing of 5 Statutory Instruments ('SIs'), each of which included a 'bundle' thematically linked amendments. ${ }^{7}$ Three of these Sls came into force on 1 June, ${ }^{8}$ with the remaining two coming into effect on 1 October. $^{9}$ The difference in commencement dates was not part of the initial intent of the Government and occurred due to a request by the Joint Committee on

\footnotetext{
${ }^{6}$ As discussed below at section 2.2, a new exception (section 28B) permitting a person who legitimately acquires content to make a personal copy for private use was introduced into the CDPA, but subsequently the decision to introduce that exception was subject to an application for judicial review and the exception was quashed.

${ }^{7}$ Explanatory Notes to the Copyright and Rights in Performances (Research, Education, Libraries and Archives) Regulations 2014, SI 2014/1372, para 4.5 'In determining the most appropriate way to group these regulations together, the Government has taken account of several factors, including any relevant legal interconnections (e.g. the impact on consequential amendments), commonality of themes (e.g. research and education), novelty or public profile and other policy considerations'.

${ }^{8}$ Copyright and Rights in Performances (Research, Education, Libraries and Archives) Regulations 2014, SI 2014/1372; Copyright and Rights in Performance (Disability) Regulations 2014, SI 2014/1384; Copyright (Public Administration) Regulations 2014, SI 2014/1385.

${ }^{9}$ Copyright and Rights in Performances (Quotation and Parody) Regulations 2014, SI 2014/2356; Copyright and Rights in Performances (Personally Copies for Private Use) Regulations 2014, SI 2014/2361.
} 
Statutory Instruments for further time to permit the Committee to engage in further scrutiny of the final two SIs. ${ }^{10}$

The new fair dealing exceptions cannot generally be set aside by contract, whereas the amended sector specific exceptions (such as those directed to libraries or educational institutions) have a more complex interaction with contract law. All of the completely new exceptions (quotation, parody, text and data mining) include a provision providing that 'to the extent that a term of a contract purports to prevent or restrict the doing of any act which, by virtue of this section, would not infringe copyright, that term is unenforceable'. ${ }^{11}$ The same provision was incorporated into the amended exceptions for research and private study, illustration for instruction, interlibrary loans and recoding of broadcasts for archival purposes. However, some of the amended exceptions include no provision in relation to inconsistent contractual provisions (such as the exceptions which permits librarians to provide single copies of unpublished works, record folk songs, and provisions relating to materials open for public inspection); and others include provisions which mediate a more complex relationship between copyright exceptions and contract. For example, the amended exception which permits the recording of broadcasts by educational establishments provides that the copyright exception will not operate 'if, or to the extent that, licences are available authorising the acts in question and the educational establishment responsible for those acts knew or ought to have been aware of [the availability of a licence]'. ${ }^{12}$

\footnotetext{
${ }^{10}$ James Younger, Intellectual Property Minister, 'Progress of the exceptions to copyright regulations' (gov.uk, 8 May 2014), < https://www.gov.uk/government/news/progress-of-the-exceptions-to-copyright-regulations> accessed 1 September 2015.
} 


\subsection{Process towards implementation}

There have been a significant number of recent partial reviews of UK Copyright law over the last decade, which form an important part of the legislative and policy backdrop to the recent amendments. ${ }^{13}$ Many of the recently implemented UK amendments were initially considered in the Government commissioned Gowers Review of Intellectual Property, ${ }^{14}$ prepared by Andrew Gowers and released in December 2006. This review proposed (amongst other changes) a limited private copying exception and an exception to permit caricature, parody and pastiche. ${ }^{15}$ While the Gowers review did not address the relationship between copyright exceptions and contract, ${ }^{16}$ it did recommend the creation of an independent strategic IP policy body to advise government, the Strategic Advisory Board for Intellectual Property ('SABIP'). ${ }^{17}$ Following the Gowers review, SABIP was established in June 2008 as an independent input into government policy making, ${ }^{18}$ and it shortly thereafter identified the relationship between copyright and contract as one of strategic importance to the UK. ${ }^{19}$ SABIP commissioned research into this relationship, and a report entitled 'The

\footnotetext{
${ }^{11}$ See for example the parody exception provisions, CDPA $1988 \mathrm{~s} 30 \mathrm{~A}(2)$ (as amended).

${ }^{12}$ CDPA 1988 s 35(4) (as amended).

${ }^{13}$ R Arnold, 'The need for a new Copyright Act: a case study in law reform' (2015) 5 QMJIP 110, 119.

${ }^{14}$ A Gowers, 'Gowers Review of Intellectual Property' (Her Majesty's Stationery Office 2006) ('Gowers Review')

${ }^{15}$ Ibid 6, and 63. While draft statutory instruments were prepared following Gowers to implement these exceptions, they did not address the relationship between copyright exceptions and contract and were ultimately not implemented.

${ }^{16}$ Ibid. The Gowers review did however mention the related issue of DRM technology being used to prevent activities permitted under copyright exceptions at page 73 .

17 Ibid 112.

${ }^{18}$ Strategic Advisory Board for Intellectual Property, Strategic Priorities for Copyright (SABIP March 2009) <no longer accessible at www.sabip.co.uk, but stored version available at http://www.ppa.co.uk/legal-and-publicaffairs/ppa-responses-and-evidence/ /media/A713F0DB066A4749AF508DC53F1639EF.ashx> accessed 1 September 2015, 1.

19 Ibid 2 and 17-18.
} 
Relationship between Copyright and Contract Law' prepared by Professor Martin Kretchmer, Professor Estelle Derclaye, Dr Marcella Favale and Professor Richard Watt was published in $2010 .^{20}$ The commissioned report concluded that limiting the enforceability of contracts to protect copyright users could not be done effectively outside the copyright legislative framework. ${ }^{21}$ However, shortly after the report was released, SABIP was dissolved by the UK Government ${ }^{22}$ and thereafter the SABIP report appears to have had limited direct impact on government policymaking.

The more immediate impetus for the recent amendments to the relationship between copyright exceptions and contract was the May 2011 Report 'Digital Opportunity: A review of Intellectual Property and Growth', chaired by Professor lan Hargreaves ('the Hargreaves Report' ${ }^{2}{ }^{23}$ Professor Hargreaves was commissioned in that report to consider the extent to which the intellectual property framework was sufficiently well designed to promote innovation and economic growth in the UK. The report made a number of significant recommendations for reform, including establishing a Digital Copyright Exchange, permitting the licensing of orphan works, and introducing new copyright exceptions for format shifting, parody, non-commercial research and library archiving. ${ }^{24}$ The report also proposed that any new exceptions introduced into the CDPA should not be capable of being

\footnotetext{
${ }^{20}$ Kretschmer and others (n 5).

21 Ibid 134.

22 J Phillips, 'SABIP' (The IPKat Blog, 19 July 2010) <http://ipkitten.blogspot.co.uk/2010/07/sabip.html> accessed 1 September 2015.

${ }^{23}$ Ian Hargreaves, 'Digital Opportunity: A Review of Intellectual Property and Growth' (Department for Business, Innovation \& Skills 2011) <http://www.ipo.gov.uk/ipreview-finalreport.pdf>accessed 1 September 2015.

${ }^{24}$ Ibid 8.
} 
set aside by contract. ${ }^{25}$ Somewhat surprisingly, while the Hargreaves report made several references to SABIP and a number of its commissioned reports, it did not expressly mention or draw upon 'The Relationship between Copyright and Contract Law' SABIP report, despite the significant overlap in subject matter and recommendations.

In August 2011, after the Hargreaves report was published, the UK Government released a formal response indicating that it broadly accepted the recommendations of the Hargreaves Report and would implement new exceptions. ${ }^{26}$ This was followed by a significant period of public, stakeholder and legislative scrutiny, and a public consultation on the proposed changes was held between December 2011 and March 2012. ${ }^{27}$ In December 2012 the Government released its response to the feedback received in the consultations in a report named 'Modernising Copyright' ${ }^{28}$ In that response the Government indicated that it would legislate for a new system of permitted acts for copyright works and would make the changes by way of Statutory Instrument which they would make available for public scrutiny. ${ }^{29}$ In June 2013 the Intellectual Property Office published the first set of draft secondary legislation for technical review and sought public comment on the drafting of the

\footnotetext{
${ }^{25}$ Ibid 51.

${ }^{26}$ Intellectual Property Office, 'The Government Response to the Hargreaves Review of Intellectual Property and Growth' (Intellectual Property Office 2011) < https://www.gov.uk/government/publications/hargreavesreview-of-intellectual-property-and-growth-government-response> accessed 1 September 2015, foreword ('Government Response to Hargreaves')

${ }^{27}$ Explanatory Notes to the Copyright and Rights in Performances (Personally Copies for Private Use) Regulations 2014, SI 2014/2361, para 7.4.

${ }^{28}$ Intellectual Property Office, 'Modernising Copyright: A Modern, Robust and Flexible Framework: Government response to copyright exceptions, and clarifying copyright law' (Intellectual Property Office 2012) <http://webarchive.nationalarchives.gov.uk/20140603093549/http://www.ipo.gov.uk/response-2011copyright-final.pdf> accessed 1 September 2015 ('Modernising Copyright').

${ }^{29}$ Ibid 21.
} 
provisions. ${ }^{30}$ The amendments were also subject to debate in the Delegated Legislation Committee $^{31}$ and the Secondary Legislation Scrutiny Committee ${ }^{32}$ and were considered by the Joint Committee on Statutory Instruments, ${ }^{33}$ before being approved by Parliament. The first set of 3 Sls were made on 19 May and came into force on 1 June 2014, while the remaining Sls were made on 26 August and came into effect on 1 October 2014.

The various amendments to the CDPA amending and introducing new copyright exceptions were controversially made as delegated legislation, in the form of statutory instruments, rather than being introduced as Bills. While most seem to accept that the Government had the power to introduce the amendments in the form of $\mathrm{Sls}^{34}{ }^{34}$ there was criticism of that choice on the basis that doing so permitted the Parliament less scope for debate and scrutiny than if the exceptions had been introduced as Bills. Furthermore, introducing the changes to the CDPA as SIs limited the ability for Parliamentarians to potentially amend their provisions and they were instead only able to vote on whether to accept or reject them in their existing form. ${ }^{35}$

\footnotetext{
${ }^{30}$ Iona Silverman, 'Newsflash: draft legislation on copyright exceptions' (The 1709 Blog, 7 June 2013) <http://the1709blog.blogspot.co.uk/2013/06/newsflash-draft-legislation-on.html> accessed 1 September 2015. ${ }^{31}$ Delegated Legislation Committee Deb 12 May 2014, Cols $3-22$ <http://www.publications.parliament.uk/pa/cm201314/cmgeneral/deleg4/140512/140512s01.pdf> accessed 1 September 2015; Delegated Legislation Committee Deb 9 July 2014, Cols 3 - 18 <http://www.publications.parliament.uk/pa/cm201415/cmgeneral/deleg10/140709/140709s01.pdf> accessed 1 September 2015.

${ }^{32}$ The Secondary Legislation Scrutiny Committee transcript of evidence 6 May 2014, questions 1-13 $<$ http://www.parliament.uk/documents/lords-committees/Secondary-Legislation-ScrutinyCommittee/SLSC Revise Ev TRANS.pdf> accessed 1 September 2015.

${ }^{33}$ Joint Committee on Statutory Instruments, Twenty-sixth Report of Session (2013-14 HL 183, HC 166-xxvi) 2; Joint Committee on Statutory Instruments, Third Report of Session (2014-2015 HL 13, HC 332-iii) 16-20.

${ }^{34}$ HL Deb 29 July 2014, vol 755 col 1558; Delegated Legislation Committee Deb 12 May 2014, col 13.

${ }^{35}$ HL Deb 29 July 2014, col 1559.
} 
The new amendments remained controversial after coming into effect. In an application for judicial review in November 2014 representatives of the music industry ${ }^{36}$ challenged the decision by the Secretary for State for Business, Innovation and Skills to introduce the exception permitting the making of copies for personal private use. ${ }^{37}$ The music industry representatives argued that the private use exception could not be introduced without the payment of fair compensation to rightholders. ${ }^{38}$ The application for judicial review was ultimately successful and the exception was quashed with prospective effect. ${ }^{39}$ This decision was reached on the basis that the evidence relied upon by the Secretary for State concerning possible harm to rightholders caused by introducing the exception was inadequate. ${ }^{40}$ It remains open for the Secretary of State to engage in further factual enquiries on the issue of harm to rightholders and after doing so may reintroduce a private copying exception at a later date. ${ }^{41}$ The case did not however examine the provisions

\footnotetext{
${ }^{36}$ Namely the British Academy of Songwriters, Composers and Authors, the Musicians Union and UK Music. ${ }^{37} R$ (on the application of BASCA \& Ors v Secretary of State for Business, Innovation and Skills [2015] EWHC 1723 (Admin) in which the application for judicial review succeeded, with a subsequent judgment dealing with consequences flowing from that decision in $R$ (on the application of BASCA \& Ors $v$ Secretary of State for Business, Innovation and Skills [2015] EWHC 2041 (Admin).

${ }^{38}$ Amongst other grounds, the Claimants argued that if a private use exception could only be implemented if it complied with the requirement of payment of fair compensation to rightholders in accordance with Article 5(2)(b) of Council Directive 2001/29/EC of 22 May 2001 on the harmonisation of certain aspects of copyright and related rights in the information society [2001] OJ L167/10 ('the Information Society Directive'). The Secretary of State referred to Recital 35 to the Information Society Directive (providing that 'In certain situations where the prejudice to the rightholder would be minimal, no obligation for payment may arise') and argued that no compensation was payable as the introduction of the section was expected to lead to minimal or zero costs to rightholders.

${ }^{39}$ In $R$ (on the application of BASCA \& Ors v Secretary of State for Business, Innovation and Skills [2015] EWHC 2041 (Admin) para 12.

${ }^{40} R$ (on the application of BASCA \& Ors v Secretary of State for Business, Innovation and Skills [2015] EWHC 1723 (Admin) para 269- 273.

${ }^{41}$ For further information on the case see E Rosati, 'Green J quashes UK private copying regulations' (IPKat Blog, 20 July 2015)

<http://ipkitten.blogspot.co.uk/search/label/BASCA\%20and\%200thers\%20v\%20Secretary\%20of\%20State\%20f or\%20Business\%20Innovation\%20\%26\%20Skills\%20\%5B2015\%5D\%20EWHC\%202041\%20(Admin)> accessed 1
} 
relating to the relationship between contract and copyright exceptions within the challenged personal use exception provision. The contractual override provisions therefore remain untested in litigation and continue to operate within the remaining recently introduced amendments.

\subsection{Why did the Government seek to change the relationship between copyright} exceptions and contract?

Despite a significant degree of public consultation and Parliamentary debate, the UK Government has provided only brief statements as to the rationale for the amendments to the relationship between copyright exceptions and contract. Below I sketch out the various comments made in relation to the issue by Government representatives during the amendments process, in order to extract the underlying rationale of the changes.

At the outset of the review process the Hargreaves report discussed the relationship between copyright exceptions and contract. In recommending that the proposed copyright exceptions should not be capable of being set aside by contract, the report argued that mandatory exceptions would minimize uncertainty, maintain balance between rightsholders and users, and prevent rightsholders from re-writing the limits of the property rights bestowed upon them. The report began its consideration of copyright exceptions by noting

September 2015; E Rosati, 'Lack of fair compensation requirement in UK private copying exception not supported by sufficient evidence, High Court rules' (IPKat Blog, 19 June 2015) <http://ipkitten.blogspot.co.uk/2015/06/lack-of-fair-compensation-requirement.html> accessed 1 September 2015 and J Thomas, 'Fair compensation for copyright holders - the UK's personal copying exception' (LexisNexis 
that they were generally 'designed to allow uses of content that offer benefits deemed either more important than those delivered by the core aims of copyright and/or benefits that do not significantly detract from those aims' ${ }^{42}$ This rationale for exceptions is consistent with the earlier Gowers Review, which stated that English fair dealing copyright exceptions exist to permit uses which would not otherwise occur due to transaction costs and to also permit uses which are consistent with basic rights. ${ }^{43}$ The Hargreaves Report argued that without mandatory exceptions there would be considerable uncertainty for users within the education sector as to whether they could rely on statutory copyright exceptions, ${ }^{44}$ or whether instead they would need to consult the terms of a licence before making use of an exception. ${ }^{45}$ In support of this argument, the report noted a study by the Libraries and Archives Copyright Alliance of contracts offered to the British Library, which found that contracts routinely attempted to set aside exceptions and that there was significant diversity between licence terms offered by rightsholders. ${ }^{46}$ The report expressed a concern that a consequence of this was that risk adverse library and academic administrators, such as those at the British Library, who had entered into contracts with many providers might restrict users' access to the most restrictive set of terms, in order to be certain that contractual licences were not being breached. The report was also critical of the ability of rightsholders to 'rewrite the limits the law has set on the extent of the right conferred by copyright', ${ }^{47}$ and

World of IP and IT Law, 23 June 2015) <http://blogs.lexisnexis.co.uk/wipit/fair-compensation-for-copyrightholders-the-uks-personal-copying-exception/> accessed 1 September 2015.

\footnotetext{
42 Hargreaves (n 23) 42.

${ }^{43}$ Gowers, (n 14) 61.

${ }^{44}$ Hargreaves (n 23) 41.

${ }^{45}$ Ibid 51.

46 Ibid.

47 Ibid.
} 
it further recommended that the Government should legislate to ensure that both the existing and proposed new copyright exceptions could not be set aside by contract. ${ }^{48}$

In the UK Government's formal response to the Hargreaves Report it indicated that it would seek to ensure that 'unnecessary restrictions removed by copyright exceptions are not re-imposed by other means, such as contractual terms, in such a way as to undermine the benefits of the exception' ${ }^{49}$ In the subsequent period of public consultations a number of rightsholders emphasized the importance of the principle of freedom to contract, ${ }^{50}$ and the Government in response noted that:

[a]t their best [licenses] may create clarity and enable far more than the limited permitted acts allowed under European law. At their worst they can erode socially and economically important uses of copyright works. The Government wishes to mitigate these negative effects while allowing the former. ${ }^{51}$

In the Government's response to the consultation it expressed its aim as 'not to establish contract as superior to permitted act or vice versa, but to ensure licensing does not restrict acts that are beneficial to society as a whole' ${ }^{52}$ This rationale was later reemphasized by the Minister for Intellectual Property at the Department for Business Innovation and Skills in a

\footnotetext{
48 Ibid.

${ }^{49}$ Intellectual Property Office, Government Response to Hargreaves (n 26) 8.

50 Intellectual Property Office, 'Consultation on Copyright Summary of Responses' (Intellectual Property Office 2012) <https://www.gov.uk/Government/uploads/system/uploads/attachment data/file/320223/copyrightconsultation-summary-of-responses.pdf> accessed 1 September 2015 27; cf Intellectual Property Office, Modernising Copyright (n 28) 18.

${ }^{51}$ Intellectual Property Office, Modernising Copyright (n 28) 19.

52 Ibid.
} 
letter to the Secondary Legislation Scrutiny Committee who wrote that the role of the contractual override provisions was to '...provide legal certainty and protect beneficiaries of statutory rights'. ${ }^{53}$

In summary, it appears that the UK Government's rationale for preventing copyright exceptions from being overridden by contract is twofold. First of all, mandatory exceptions provide certainty to users by allowing them to rely on the statutory rules, rather than being forced to consult the terms of a licence. Secondly, they also prevent rightsholders from acting in a way which undermines the benefit of the exceptions to society, by using contract to prevent users from relying on the statutory exceptions. The next section of this paper considers the extent to which, despite the new legislation and Government intention, rightsholders may be able to undermine the benefit of existing exceptions with contract.

\section{Issues with the UK amendments as implemented}

\subsection{Contractual override does not apply to all exceptions within the CDPA}

While the Hargreaves Report suggested that the Government should legislate to ensure that both existing and proposed exceptions could not be set aside by contract, the

\footnotetext{
${ }^{53}$ Letter from Viscount Younger of Leckie, Minister for Intelectual Property to Lord Goodlad, Chairman of the Secondary Legislation Scrutiny (12 May 2014)

<http://www.publications.parliament.uk/pa/ld201314/ldselect/ldsecleg/186/18609.htm> accessed on 1 September 2015. Interestingly, in the UK copyright exceptions are generally considered to be user privileges, rather than statutory rights, which makes the ministers indirect reference to protecting beneficiaries of statutory rights an interesting comment. The Minister may however have been referring to the purpose of contractual override provisions more broadly, which more commonly tend to be used to protect statutory rights, rather than mere privileges.
} 
recent amendments did not implement contractual override provisions in relation to all preexisting exceptions in the CDPA. This result is noted by Lionel Bently and Brad Sherman in the most recent edition of their influential intellectual property text, where the authors identify that after the amendments not all copyright exceptions in the CDPA include a contractual override clause, and indeed that '[b]izarrely... the effect is that contractual limitations remain possible in relation to the core public interest exceptions... ${ }^{54}$ The authors do not consider the failure to redraft these exceptions to include contractual override provisions as deliberate, noting that at least in relation to the core public interest exception of fair dealing for criticism and review and reporting current events the situation is likely only to persist 'until the Government embarks on the much needed codification' ${ }^{55}$

Due to the Government's failure to review the existing fair dealing exceptions in the CDPA during the recent round of amendments, there is no explicit contract override provisions in the CDPA for some of the key public interest copyright exceptions, such as criticism, review and news reporting. ${ }^{56}$ An argument might however be made that despite the lack of an explicit clause concerning contractual override in some parts of the CDPA, as a matter of domestic UK statutory interpretation all exceptions within the CDPA should be understood as mandatory. This argument might be made with reference to the purpose of copyright exceptions within the CDPA, their role in furthering the public interest and the fact that many exceptions further the human right to freedom of expression. A similar argument

\footnotetext{
${ }^{54}$ L Bently and B Sherman, Intellectual Property Law (4th edn, Oxford University Press 2014) 229. 55 Ibid.

${ }^{56}$ CDPA 1988 s 30(1), although an override provision exists in relation to the new fair dealing for the purpose of quotation, which may overlap with activities permitted under the criticism and review fair dealing exception. Note also that as mentioned above s 137 of the Broadcasting Act 1996 also prohibits contractual restrictions on
} 
was considered in the 2002 Australian Copyright and Contract report ${ }^{57}$ in relation to

Australian fair dealing exceptions, where as in the UK, one difficulty of adopting such an interpretation is that explicit contractual override provisions preexisted in relation to computer program exceptions. Furthermore, in the UK a provision also exists in section 137 of the Broadcasting Act (1996), which provides that 'Any provision in an agreement is void in so far as it purports to prohibit or restrict relevant dealing with a broadcast or cable programme in any circumstances where by virtue of section 30(2) of the [CDPA] copyright in the broadcast or cable programme is not infringed' ${ }^{58}$

As a result, an application of the expressio unius est exclusio alterius ${ }^{59}$ cannon of construction might lead to a conclusion that the existence of express contractual override provisions in the Australian and UK Acts means that the other exceptions are capable of being set aside by contract. An argument for all exceptions being mandatory may also be difficult to sustain in circumstances where a small number of the recently amended UK exceptions were deliberately drafted to permit contractual override. ${ }^{60}$ Accordingly, it is likely

reporting current affairs in relation to sports events, and so the fair dealing for reporting current events exception is s 30(2) CDPA is protected from override in some limited circumstances.

${ }^{57}$ Copyright Law Review Commission, Copyright and Contract (Copyright Law Review Committee 2002).

58 In other words, this provision provides that a broadcast or cable programme copyright owner cannot use contract to seek to prevent or restrict a fair dealing for the purpose of reporting current events. This section of the Broadvasting Act 1996 derived from an amendment proposed by the then Minister for Sport lan Sproat, and was included in the bill without debate or significant comment: see Hansard HC vol 280 col 591 (1 July 1996). The amendment was made in the context of changes being made to the law in relation to 'listed events', to ensure that key sporting events were made available to all television viewers, particularly those who could not afford the extra cost of subscription television. The section is described by Jonathan Griffiths as being inteded to ensure that 'short extracts of sporting events [are] available for news reporting purposes whatever the source.' J Griffiths 'United Kingdom' in R Hilty and S Nérisson (eds), Balancing Copyright - A Survey of National Approaches (Springer, 2012) 1069.

${ }^{59}$ To express one thing is by implication to exclude another.

${ }^{60}$ Intellectual Property Office, 'Technical Review of Draft Legislation on Copyright Exceptions: Government Response' (Intellectual Property Office 2014)

<https://www.gov.uk/government/uploads/system/uploads/attachment data/file/308732/responsecopyright-techreview.pdf> accessed 1 September 2015, 15: 'A number of respondents commented that some 
that as a matter of domestic UK law unless a fair dealing exception has an explicit clause dealing with its relationship with contract, that exception will be treated by a court as being capable of being set aside by contract.

Going beyond a purely domestic interpretation of the CDPA, the UK Department for Business, Innovation and Skills argued that as part of the reform process that in the EU unless contract or licence terms are expressly allowed to limit the scope of an exception in legislation, the default positon is that under EU law the exception will prevail over any rightsholder authorisation. ${ }^{61}$ This proposition was expressed by the Department as arising from the ECJ Judgment in VG Wort. ${ }^{62}$ This is an arguably incorrect interpretation of the VG Wort Judgment, ${ }^{63}$ but if considered persuasive by a UK court it would mean that the

of the amended sections did not include a provision to bar contracts from overriding the exception. The Government's policy is to prevent exceptions from being undermined by contracts, as long as such use is fair. The Government has therefore inserted the missing contract override provisions for the exceptions where libraries make single copies of published works and where libraries supply single copies to other libraries. No contract override provision is included in the dedicated terminals exception, in line with the Copyright Directive. Nor is one included where libraries make copies of unpublished works, in line with the existing provision which allows the copyright owner to prohibit copying of the work' ('Government Response to Technical Review').

${ }^{61}$ Voluntary memorandum from the Department for Business, Innovation and Skills to the Statutory Instruments Joint Committee (27 March 2014) <http://www.publications.parliament.uk/pa/jt201415/jtselect/jtstatin/13/1321.htm> accessed 1 September 2015.

${ }^{62}$ Joined Cases C-457/11 to C-460/11 Verwertungsgesellschaft Wort (VG Wort) v Kyocera and Others (ECJ, 27 June 2013), ('VG Wort').

${ }^{63} \mathrm{I}$ argue that the UK Department for Business, Innovation and Skills may be wrong to describe the situation as a default position. Instead, it is arguable that following VG Wort the ECJ goes further, and that where a Member State has introduced an exception to the right of reproduction 'any authorising act the rightholders may adopt is devoid of legal effects under the law of that State' (para 37) - in other words any attempt to utilise contract to exclude the operation of an exception would be ineffectual. While it could be argued that a 'default rule' style exception to copyright exception would instead by classified by the Court in VG Wort as a limitation where the reproduction right has been preserved to the rightholder (para 38 and 39), this approach is inconsistent with the jurisprudence of the ECJ on the extent to which exceptions and limitations are harmonized across the EU (see for example Case C-435/12 ACI Adam BV and Others v Stichting de Thuiskopie and Stichting Onderhandelingen Thuiskopie vergoeding (ECJ, 10 April 2014) para 34), and would be inconsistent with Recitals 31 and 32 of the Information Society Directive, which seek that member states arrive at 'a coherent application of [the] exceptions and limitations'. 
remaining unamended copyright exceptions may be mandatory, even in the absence of the much needed codification of the CDPA discussed by Bently and Sherman.

\subsection{Significance of 'void' vs 'unenforceable'}

The new copyright exception provisions provide that contractual terms which restrict the new exceptions are 'unenforceable'. This stands in contrast to the existing provision in the CDPA in relation to copyright exceptions permitting backup copies, decompilation and testing of a computer program ('computer program exceptions'), ${ }^{64}$ which provide that certain terms in an agreement 'shall be void' ${ }^{65}$ Similarly, the existing provision in section 137 of the Broadcasting Act relating to contractual override and fair dealing for the purpose of reporting current events provides that 'Any provision in an agreement is void...'. The preparatory material for the new exceptions do not conclusively address what consequences the drafter intended by introducing a distinction between void contractual terms and unenforceable contractual terms, or whether the difference in terminology in different sections of the CDPA was merely an oversight. Part of the difficulty in anticipating the outcome if a suspect contract was challenged in court is that there is uncertainty as to the significance of a contract being void. This uncertainty flows from the inexact way in which courts have in the past used the word void to signify both contracts that are void $a b$ initio

\footnotetext{
${ }^{64}$ CDPA 1988 s 38.

${ }^{65}$ CDPA 1988 s 296A.
} 
and contracts which are merely voidable by one party. ${ }^{66}$ This uncertainty is compounded where the legislation provides that only the impugned term is considered to be void, rather than the contract as a whole.

One possible explanation for the difference in language is that the pre-existing computer program exceptions were drafted to implement Article 8 and Recital 16 to Directive 2009/24/EC on the Legal Protection of Computer Programs, which requires Member States to provide that certain contractual provisions 'shall be null and void' ${ }^{67}$ In contrast, the contractual provisions in the new exceptions are not intended to implement an EU directive and the drafters therefore may have felt less constrained in their choice of statutory language. $^{68}$

While in the technical review the Intellectual Property Office implied a substantive difference between void and unenforceable terms, ${ }^{69}$ the Office was not explicit as to what it saw as the result of the drafting difference. Similarly, Viscount Younger of Leckie, the Parliamentary Under-Secretary of State, Department for Business, Innovation and Skills, explained to the House of Lords Grand Committee that a court's approach to void and unenforceable terms was 'slightly different' and that 'rendering the term void would be a

\footnotetext{
${ }^{66}$ A Levin, 'The Varying Meaning and Legal Effect of the Word "Void"' (1934) 32 Michigan Law Review 1088, 1092.

${ }^{67}$ Council Directive 2009/24/EC of 23 April 2009 on the Legal Protection of Computer Programs (Codified version) [2009] [OJ L111/16].

${ }^{68}$ Note that however s 137 of the Broadcasting Act 1996 was not drafted to implement an EU directive. There is limited material available to suggest why that statutory provision was drafted using the term void rather than unenforceable. See the discussion at footnote 50 above.

${ }^{69}$ Intellectual Property Office, Government Response to Technical Review (n 60) 2, 'The draft legislation contains clauses providing that to the extent that any contractual terms purport to prevent or restrict the doing of a permitted act allowed by a copyright exception, those terms are unenforceable. This language does not void the term of any contract'.
} 
disproportionate measure in many cases ${ }^{\prime},{ }^{70}$ but again did not explain what the difference

was.

It is difficult to anticipate whether a UK court would discern a difference in outcome between an impugned contract with an unenforceable term and a contract with a void term. In most instances where such contracts would be challenged in court there would be a licence agreement whereby the rightsholder granted permission for certain uses of a copyright protected work, while the user paid a license fee for those uses. In such circumstances, a determination that a single term of the agreement relating to copyright exceptions was void is likely to be severable from the balance of the agreement, on the basis that striking out that term would not entirely alter the scope and intention of the agreement. Similarly, if a single term of the agreement was unenforceable the remaining terms of the agreement are likely to be unaffected. Indeed, the intent of the drafters was that where one term of a contract is unenforceable the '[o]ther contract clauses will be unaffected' ${ }^{71}$ In the usual course of events therefore there is unlikely to be a distinction of significance between categorising terms as void or unenforceable.

One underexplored area in the copyright literature where a possible difference between void and unenforceable terms could potentially have legal significance is in the unlikely event that the only contractual consideration from one party to a contract was a promise not to utilize one of the recently introduced fair dealing exceptions. ${ }^{72}$ If a user

\footnotetext{
${ }^{70}$ HL Deb 5 December 2013, vol 750, col GC78.

${ }^{71}$ Intellectual Property Office, Government Response to Technical Review (n 60) 2.

72 This may occur where a musician or director wishes to prevent the creation of a parody of their work under the new CDPA 1988 s 30A Parody exception by a particular individual. Assuming the individual user already has access to the work, the musician or director may wish to pay the potential parodist in exchange for a promise from them to not parody the specific work. The contractual promise not to parody a work would be
} 
accepted the payment in exchange and subsequently broke their promise not to utilize an

exception, then as the users sole contractual consideration has been removed, the categorisation of the user's broken promise as either void or unenforceable may have some impact on a court's decision in relation to whether the payment by the rightsholder is

recoverable. ${ }^{73}$ Outside of this narrow case however the distinction drawn in the legislation is of limited practical significance and it is argued that the Government's goal of reducing uncertainty may have been better served by drafting the language of the new provisions in the CDPA consistently with the existing contractual override provisions relating to computer program exceptions.

\subsection{Meaning of 'restrict doing any act'}

The provision in the new copyright amendments preventing contractual override operates where 'a term of a contract purports to prevent or restrict the doing of any act' permitted by the relevant exception. While it is not controversial to consider that a contractual clause forbidding a user from engaging in an act would clearly 'purport to prevent' within the meaning of the provision, it is less clear when a term of a contract will merely 'restrict' the doing of an act. For example, it is unclear whether the payment of a license fee in exchange for being permitted to engage in a use of a work would be

unenforceable due to the new CDPA $1988 \mathrm{~s} 30 \mathrm{~A}(2)$. This hypothetical is however contingent on the parodist already having lawful access to the work such that the contract does not include both a standard licence permitting access to the work, in addition to the specific term in relation to the parody.

73 J Schaefer, 'Beyond a Definition: Understanding the Nature of Void and Voidable Contracts' (2010) 33 Campbell Law Review 192, 200, noting the distinction between an unenforcable contract and void contract in American law is that the law recognizes an abstract duty of performance only in relation to the former case. 
interpreted as a restriction on engaging in that use. On one understanding, the payment of the royalty fee does not restrict the use and instead merely acts to confirm that the use is permitted.

Many UK copyright exceptions apply only where a use is considered fair, with discretion left to the courts to determine when a specific use is considered to be a fair dealing. Risk averse parties may wish to include in their contracts criteria which assist them to determine when a particular contemplated use is either fair or unfair, to avoid recourse to litigation in the event of a dispute. For example, a copyright owner might enter into a contract with a parodist of their work, where in exchange for payment they authorise the party and negotiate how much of the original work can be reused, the ways the parody could be commercially distributed and other circumstances under which the parties consider the parody to be a fair dealing. Conceived of in another way however the payment places a financial burden on the parodist, financially restricting their ability to parody original works and might therefore fall within the category of terms which restrict the doing of an act permitted by the relevant exception. It is unclear whether such a payment would qualify as a restriction and therefore whether such contractual terms would be unenforceable. The new exceptions and their explanatory material do not provide helpful guidance on this issue, although one factor which might be relevant in resolving such questions would be the extent to which the parties' contractual fairness criteria are consistent with those which a court might utilise in resolving a hypothetical fair dealing question. 


\section{Conclusion}

Despite the contractual override provisions in the new copyright exceptions it is likely that many rightsholders will continue to insert terms in contracts which purport to preclude the new fair dealing copyright exceptions. As discussed above, due to some lingering uncertainty in the scope of the amendments they may be doing this in an attempt to subvert the intention of the legislator and control utilisation of the exceptions.

There may however be legitimate reasons to seek to include such terms, even where the rightsholder is aware that they are unenforceable. For example, unenforceable terms might be included in a contract where the parties are aware of the law but instead seek to rely on a gentleman's agreement, rather than binding force of law, to ensure that terms are complied with. ${ }^{74}$ Unenforceable terms might also function as a signalling device, acting as an unenforceable signal of rightsholders' wishes in relation to certain uses of their works. ${ }^{75}$ More cynically, it is also likely that many rightsholders will include such terms in their agreement in the hope that the parties whom they contract with are either unaware that such terms are unenforceable or are unwilling to risk the expense of litigation to vindicate their rights. $^{76}$

In circumstances where contractual provisions setting aside copyright exceptions are permitted in other major jurisdictions (such as the US) it is likely that they will continue to be

\footnotetext{
${ }^{74}$ C Sullivan, 'The Puzzling Persistence of Unenforceable Contract Terms' (2009) 70 Ohio State Law Journal 1127, 1134.

${ }^{75}$ Ibid 1135.

${ }^{76}$ Ibid 1136.
} 
encountered in licence agreements offered to UK residents. It may therefore only be a matter of time before such a contractual term is challenged. 